UDC 577.22

\title{
New partners of TKS4 scaffold protein
}

\author{
S. V. Kropyvko \\ Institute of Molecular Biology and Genetics, NAS of Ukraine \\ 150, Akademika Zabolotnoho Str., Kyiv, Ukraine, 03680 \\ siryl_2000@yahoo.com
}

TKS4 scaffold protein is involved in formation of invadopodia, production of reactive oxygen species (ROS) by tumor cells and other cellular processes. Aim. To identify new TKS4 partners involved in the actin cytoskeleton rearrangements and endo-/exocytosis. Methods. The GST pull-down assay was used to identify the interaction. Results. We revealed that TKS4 SH3 domains interacted with the actin cytoskeleton reorganization proteins N-WASP and CR16, as well as with DNM2, SYNJ1 and OPHN1 which are involved in endo-/ exocytosis. We also tested the WIP, WIRE, SHIP2, RhoU, RhoV and NUMB proteins, but their interaction with the SH3 domains of TKS4 was not found. Conclusions. The SH3 domains of TKS4 interact with N-WASP, DNM2, SYNJ1, OPHN1 and weakly with CR16 in vitro.

Ke y w o r d s: TKS4, adaptor/scaffold proteins, actin cytoskeleton, endo-/exocytosis.

\section{Introduction}

Adaptor/scaffold proteins play an important role in the functioning of cells. Adaptor proteins are composed of domains and motifs that mediate molecular interactions, and can thereby link signaling proteins, e.g. activated cell-surface receptors to downstream effectors. The recent data support the notion that adaptors are not simply coupling devices that hardwire the successive components of signaling pathways [1]. Scaffold proteins usually consist of multiple domains that bind different cell components and are believed to be responsible for anchoring scaffold proteins to various microdomains of the cell. Adaptors/scaffolds often contain Src-homology 2 and 3 (SH2 and SH3) domains that bind to phosphotyrosine residues (pY) and proline-rich motifs (PxxP) respectively [2]. Usually adaptor/scaffold proteins consist of domains which can bind different membrane phospholipids such as Phox homology (PX) or pleckstrin-homology $(\mathrm{PH})$ domains [3].
TKS4 (Tyrosine kinase substrate with four SH3 domains) scaffold protein, known also as SH3PXD2B contain one PX domain, four SH3 domains, prolinerich motifs, mostly concentrated in the linker between $3^{\text {rd }}$ and $4^{\text {th }}$ SH3 domains; and three Src phosphorylation sites (Fig. 1) [4]. TKS4 was shown to play an important role in the formation of functional invadopodia [4] and lamellipodia [5] - cellular invasive and motion structures, the production of ROS by tumor cells $[6,7]$ and in the differentiation of white adipose tissue [8]. The TKS4 gene mutations are linked to such pathologies as Frank-Ter Haar syndrome [9], Borrone dermato-cardio-skeletal syndrome [10] and glaucoma [11]. It was shown that together with the other family member, TKS5 (Tyrosine kinase substrate with five SH3 domains), TKS4 plays a critical role in the cancer cell invasiveness. For instance, after the TKS4 knockdown the cancer cells lose their ability to form invadopodia [4]. The detailed mechanisms of TKS4 participation in these processes are unknown, so the search and

(C) 2015 S. V. Kropyvko; Published by the Institute of Molecular Biology and Genetics, NAS of Ukraine on behalf of Biopolymers and Cell. This is an Open Access article distributed under the terms of the Creative Commons Attribution License (http://creativecommons.org/licenses/by/4.0/), which permits unrestricted reuse, distribution, and reproduction in any medium, provided the original work is properly cited 


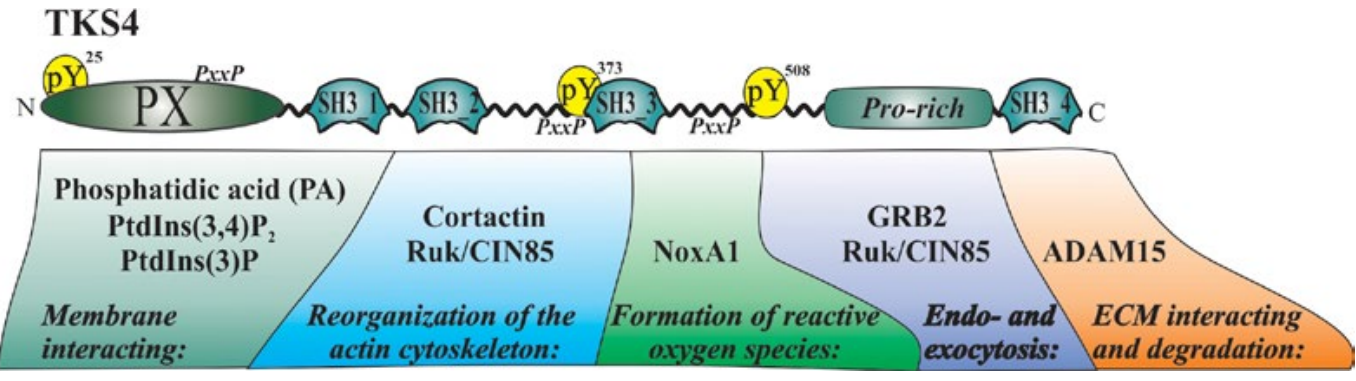

Fig. 1. Schematic presentation of the TKS4 domain structure and its known partners characterization of the new partners are an important area of research.

To date only five TKS4 protein partners are known. One of them is cortactin, a regulator of actin cytoskeleton [5]. Gianni and co-authors have shown that TKS4 participates in the ROS production by the interaction with NoxA1 (NOX activating protein 1) [7]. Another TKS4 partner is metalloprotease ADAM15 (a disintegrin and metalloprotease 15) that takes part in the extracellular matrix degradation during the cell movement and invasion. The interaction was confirmed by GST pull-down assay [12]. Mass spectrometry revealed two more partners: scaffold Ruk/CIN85 (regulator of ubiquitous kinase/ Cbl-interacting protein of $85 \mathrm{kDa}$ ) and adaptor GRB2 (growth factor receptor-bound protein 2) [13, 14]. Through the PX domain TKS4 interacts with the membrane phosphatidylinositol phosphates (such as PtdIns(3,4) $\mathrm{P}_{2}$, PtdIns(3)P and PA) which probably allow it to recognize endosomes and invadopodia formation sites (Fig. 1) [4, 15].

In this work we searched for new TKS4 partners containing proline-rich motifs which could interact with the TKS4 SH3 domains. The proteins we have chosen for GST pull-down assay are involved in the actin cytoskeleton rearrangement, endo-/exocytosis and formation of invadopodia.

\section{Materials and Methods}

\section{RT-PCR and expression constructs}

cDNA was synthesized from 1 to $5 \mu \mathrm{g}$ of total RNA using oligo $\left(\mathrm{dT}_{15}\right)$ primer and Expand Reverse Transcriptase from Roche. Five percent of the cDNA

Table 1. Primers used for cloning

\begin{tabular}{|c|c|c|c|}
\hline Constructs $^{\mathrm{a}}$ & Primers Sequence ${ }^{\mathrm{b}}$ & Sites & Shifts \\
\hline $\begin{array}{l}\text { pCMVmyc-CR16 } \\
\text { (aa 2-483) }\end{array}$ & $\begin{array}{l}\text { f_tgac[gaattc]cagtgccaccgcca } \\
\text { r_gac[ctcgag]ttcatctgtcttctc }\end{array}$ & $\begin{array}{l}\text { EcoRI } \\
\text { XhoI }\end{array}$ & $\begin{array}{l}\text { G956 to A; } \\
\text { C1039(Ala) to T(Val) }\end{array}$ \\
\hline $\begin{array}{l}\text { pRK5myc-WIRE } \\
\text { (aa 2-440) }\end{array}$ & $\begin{array}{l}\text { f_ca[ggatcc] ccaattcetcetcceccgec } \\
\text { r_cc[tctaga] acgggaccaagccaggettc }\end{array}$ & $\begin{array}{l}\text { BamHI } \\
\text { XbaI }\end{array}$ & $\mathrm{T} 228$ to $\mathrm{C}$ \\
\hline $\begin{array}{l}\text { pcDNA4maxB-N-WASP } \\
\text { (aa } 3-505)\end{array}$ & $\begin{array}{l}\text { f_at[gaattc]cgtccagcagcagccg } \\
\text { r_ta[gatatc]agtcttcccactcatc }\end{array}$ & $\begin{array}{l}\text { EcoRI } \\
\text { EcoRV }\end{array}$ & C394 to $\mathrm{T}$ \\
\hline $\begin{array}{l}\text { pGEX4T3-SH3_1(TKS4) } \\
\text { (aa 152-212) }\end{array}$ & $\begin{array}{l}\text { f_agt[gaattc]catggtcctggagca } \\
\text { r_ctc[ctcgag]cacccatcctggcc }\end{array}$ & $\begin{array}{l}\text { EcoRI } \\
\text { XhoI }\end{array}$ & \\
\hline $\begin{array}{l}\text { pGEX4T3-SH3_2(TKS4) } \\
\text { (aa 221-282) }\end{array}$ & $\begin{array}{l}\text { f_tct[gaattc]tgaagaagaggagaa } \\
\text { r_ggg[ctcgag]ggctccccactgttc }\end{array}$ & $\begin{array}{l}\text { EcoRI } \\
\text { XhoI }\end{array}$ & A845(Lys) to T(Met) \\
\hline $\begin{array}{l}\text { pGEX4T3-SH3_3(TKS4) } \\
\text { (aa 368-426) }\end{array}$ & $\begin{array}{l}\mathrm{f}_{-} \text {atc[ggatcc] caagtggaggaaga } \\
\mathrm{r}_{-} \text {tgc[ctcgag]tcttgtacttgtcaa }\end{array}$ & $\begin{array}{l}\text { BamHI } \\
\text { XhoI }\end{array}$ & \\
\hline $\begin{array}{l}\text { pGEX4T3-SH3_4(TKS4) } \\
\text { (aa 850-911) }\end{array}$ & $\begin{array}{l}\text { f_tgc[gaattc]cctgaaggactcttt } \\
\text { r_gaa[ctcgag]tcggctacggettct }\end{array}$ & $\begin{array}{l}\text { EcoRI } \\
\text { XhoI }\end{array}$ & \\
\hline
\end{tabular}

$a$ aa, amino acids;

$b$ f, forward; $r$, reverse; brackets indicate restriction enzyme sites into the primers 
obtained was used as a template for PCR as described previously [16]. The coding sequence of CR16 (NM_001080529 nucleotides [nt] 186 to 1647), WIRE (NM_133264; nt 244 to 1581), $N$-WASP (NM_003941.3; nt 344 to 1853), and four SH3 domains of TKS4 (NM_001017995; nt 624 to 807,831 to 1016,1273 to 1450 and 2718 to 2911 respectively), were PCR amplified from human cDNA using the primers listed in Table 1.

The plasmids encoding human GST-fused SH3A domain of ITSN1, omni-SYNJ1-PRD isoform d [17], HA-WIP [18] and HA-OPHN1 [19] were described previously. Flag-NUMB was a kind gift of Dr. P. P. Di Fiore [20], flag-SHIP2 was received from Dr. C. A. Mitchell [21], myc-RhoU, myc-RhoV were obtained from Dr. P. Aspenström [22, 23] and GFPDNM2 was from Dr. S. Gasman [24].

\section{Antibodies}

Monoclonal anti-HA antibodies were purchased from Covance, USA; monoclonal anti-flag (clone M2) antibodies were purchased from Sigma, USA; monoclonal anti-omni (D-8) sc-7270 and polyclonal anti-OPHN C-19 (sc-8374) antibodies were purchased from Santa Cruz Biotechnology, USA; monoclonal anti-myc 7E10 antibodies were purchased from LifeSpan Biosciences, USA; polyclonal
anti-GFP antibodies were a kind gift of Dr. V. V. Filonenko. Secondary horseradish peroxidase-labeled anti-rabbit, anti-mouse and anti-goat antibodies were purchased from Promega, USA.

\section{Cell culture and transfection}

MDA-MB-231 or 293 cell lines were maintained in Dulbecco's modified Eagle's medium (DMEM) supplemented with $10 \%$ fetal bovine serum, $50 \mathrm{U} /$ $\mathrm{ml}$ penicillin and $100 \mu \mathrm{g} / \mathrm{ml}$ streptomycin. The cells were transiently transfected with PEI (polyethyleneimine) according to the manufacturer's instructions and processed $24 \mathrm{~h}$ after transfection.

\section{GST pull-down assay and Western blot analysis}

The recombinant GST-fused proteins were obtained in Escherichia coli Top10A cells and affinity purified using glutathione-Sepharose 4B (GE Healthcare) according to the manufacturer's instructions. Lysates of transiently transfected MDAMB-231 or 293 cells were prepared in extraction buffer containing $20 \mathrm{mM}$ Tris- $\mathrm{HCl} \mathrm{pH}$ 7.4, $150 \mathrm{mM}$ $\mathrm{NaCl}, 0.5 \%$ Nonidet P40, $1 \mathrm{mM}$ EDTA, $1 \mathrm{mM}$ phenylmethylsulfonylfluoride (PMSF) and protease inhibitor cocktail from Roche and centrifuged for 10 $\min$ at $12.000 \mathrm{~g}$ at $4^{\circ} \mathrm{C}$. For pull-down experiments, 5-10 $\mu \mathrm{g}$ of GST or GST-fused proteins were bound
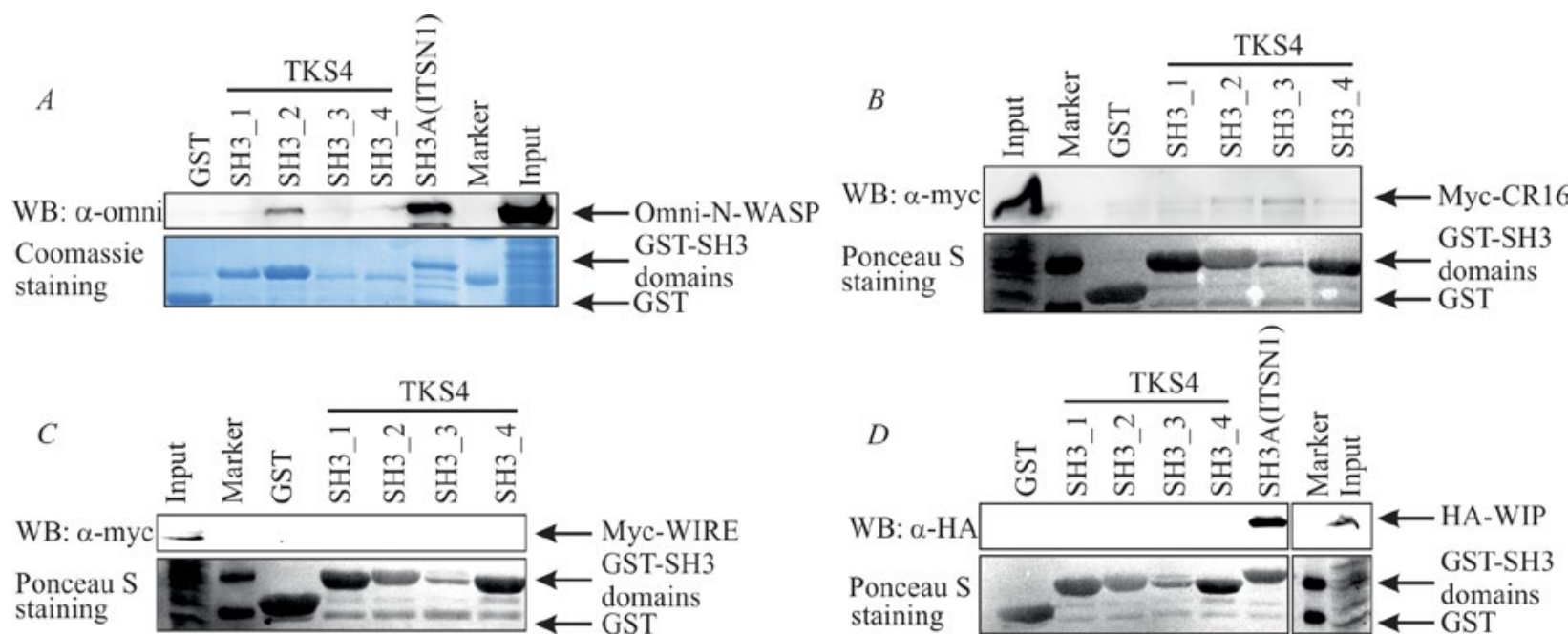

Fig. 2. The SH3 domains of TKS4 interact with the proteins involved in the actin cytoskeleton reorganization N-WASP $(A)$, CR16 $(B)$ but do not interact with WIRE $(C)$ and WIP $(D)$ 
to $30 \mu \mathrm{l}$ of $50 \%$ glutathione-Sepharose $4 \mathrm{~B}$ beads and incubated with the cell lysates for $1 \mathrm{~h}$ at $4{ }^{\circ} \mathrm{C}$. After extensive washing, the beads were boiled in Laemmli sample buffer. The proteins were resolved in SDS-PAGE, transferred to nitrocellulose membranes (Bio-Rad) and blocked in $5 \%$ nonfat milk. The membranes were incubated with primary antibodies for $1 \mathrm{~h}$ followed by incubation with peroxidase-conjugated secondary antibodies for $40 \mathrm{~min}$. Immunoreactive bands were detected using ECL reagents. Chemiluminescence was captured with Molecular Imager ChemiDoc ${ }^{\mathrm{TM}}$ XRS+ (Bio-Rad).

\section{Results and Discussion}

A GST pull-down assay was performed to test the interaction of TKS4 with the chosen protein partners

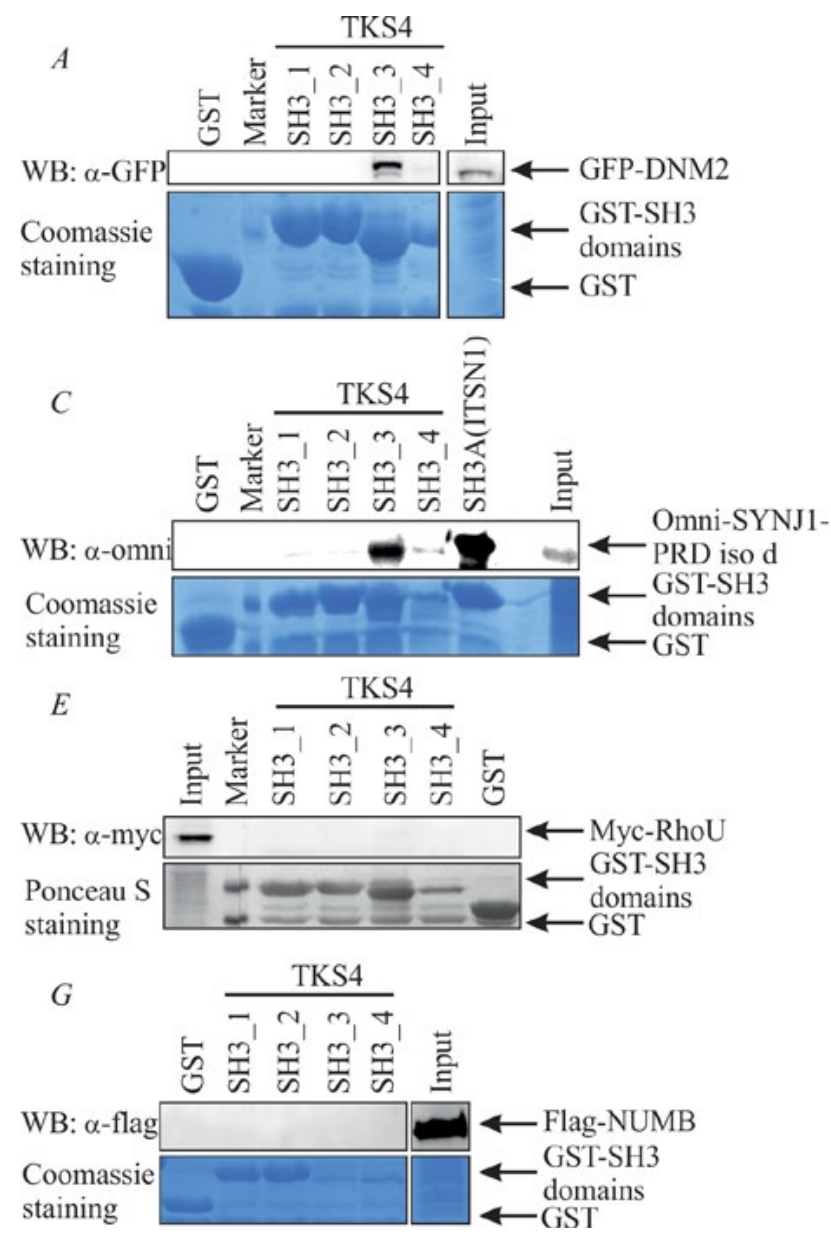

in vitro. For analysis we chose the actin cytoskeleton reorganization proteins such as N-WASP (neural Wiskott-Aldrich syndrome protein), CR16 (corticosteroids and regional expression 16), WIP (WASPinteracting protein) and WIRE (WIP-related); proteins involved in endo-/exocytosis such as DNM2 (dynamin 2), SYNJ1 (synaptojanin 1), OPHN1 (oligophrenin 1), SHIP2 (SH2 domain-containing inositol phosphate 5-phosphatase 2), NUMB (protein numb homolog) and two Rho GTPases: RhoU (Ras homolog gene family, member U) and RhoV (Ras homolog gene family, member V). Breifly, the recombinant GST-fused SH3 domains of TKS4 were immobilized on the glutathione sepharose and incubated with the lysates of MDA-MB-231 or 293 cell lines overexpressing one of the target proteins. GST
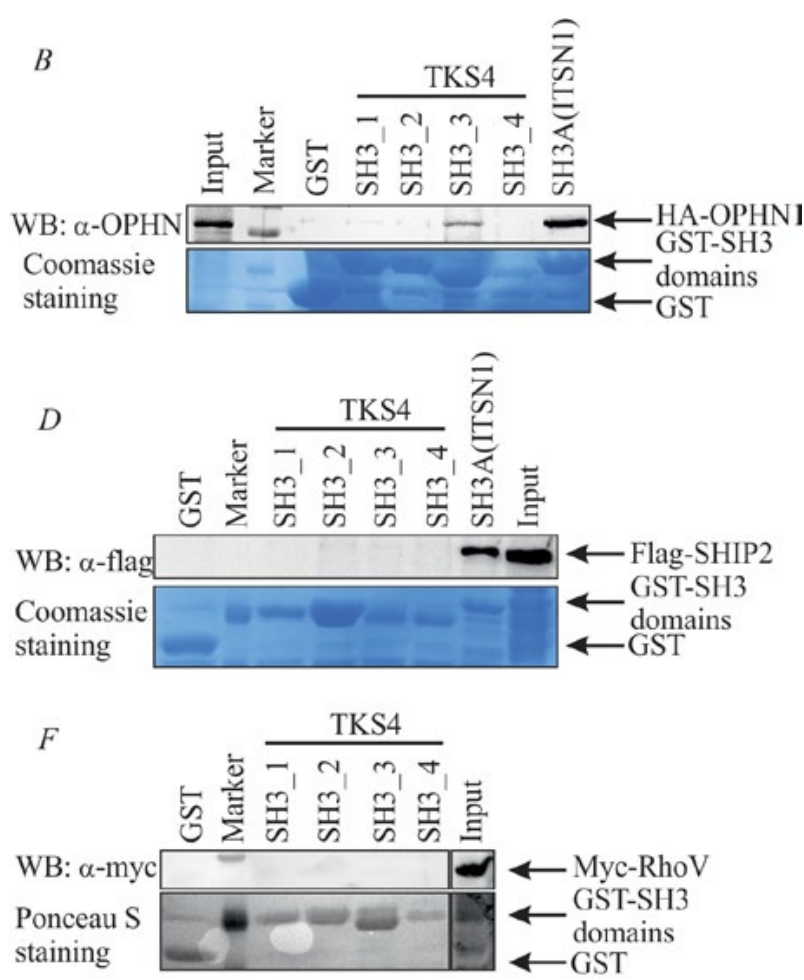

Fig. 3. The SH3 domains of TKS4 interact with proteins DNM2 $(A)$, OPHN1 $(B)$ and SYNJ1-PRD isoform $\mathrm{d}(C)$ but do not interact with SHIP2 $(D), \operatorname{RhoU}(E), \operatorname{RhoV}(F)$ and NUMB $(G)$, involved in endo-/exocytosis processes 
alone was used as a control. The amount of the GSTfused SH3 domains was detected with Coomassie or Ponceau staining. Precipitated proteins were detected by Western blot analysis. For the previously described ITSN1 partners, GST-fused ITSN1 SH3A domain was used as a positive control [17-19, 25].

First, we have tested the interaction of the TKS4 SH3 domains with the proteins involved in the actin cytoskeleton reorganization such as N-WASP and the verprolin family (WIP, WIRE and CR16) [26]. We have shown that N-WASP binds to the second TKS4 SH3 domain (Fig. 2A). CR16 demonstrated a weak interaction with the $2^{\text {nd }}, 3^{\text {rd }}$ and $4^{\text {th }}$ TKS4 SH3 domains (Fig. 2B), whereas no interaction was observed for WIRE and WIP (Fig. 2C, $D$ ).

The group of endo-/exocytosis proteins included OPHN1, GTPase activating protein for the Rho family small GTPases [27], GTPase DNM2, phosphatidylinositol phosphatases SYNJ1 and SHIP2, and scaffold protein NUMB [28]. We have also chosen two atypical members of the Rho family GTPases: RhoU and RhoV. These two atypical GTPases are highly conserved across vertebrates and involved in the adhesion and migration of many cell types [29].

After a series of GST pull-down experiments we have demonstrated the interaction of the third TKS4 SH3 domain with DNM2 and OPHN1 (Fig. 3A, $B$ ). The proline-rich domain of SYNJ1 isoform $d$ described in 2008 in our lab [17] binds to the third and weakly to the fourth TKS4 SH3 domains (Fig. 3C). No interaction was shown for SHIP2, RhoU, RhoV, and NUMB (Fig. 3D-G).

The obtained results on the TKS4 binding to N-WASP and CR16 indicate the TKS4 potential involvement in the actin cytoskeleton reorganization, which is in line with the previously demonstrated TKS4 interaction with the nucleation promoting factor cortactin [5]. TKS4 may regulate the interaction between N-WASP and CR16 which highly cooperate in the regulation of the actin cytoskeleton rearrangement [26].

The TKS4 interaction with such endo-/exocytosis components as DNM2, SYNJ1 and OPHN1 [28, 27] may bring new evidence for its participation in these membrane transport processes, which has been demonstrated for the first time. Besides, our data suggest that TKS4 is likely involved in the invadopodia formation: N-WASP and DNM2 are the key components of these invasive structures, and phosphotidylinositol phosphates (PtdInsP) that bind to the TKS4 PX domain are the markers for the invadopodia initiation sites [15]. This process, in turn, may be regulated by the TKS4 interaction with the SYNJ1 phosphatidylinositol phosphatase which dephosphorylates phosphatidylinositol bis- or trisphosphates localized in plasma membranes [30].

\section{Conclusions}

The SH3 domains of TKS4 interact with N-WASP, DNM2, SYNJ1-PRD isoform d, OPHN1 and weakly with CR16 in vitro. The interaction of the TKS4 SH3 domains with WIP, WIRE, SHIP2, RhoU, RhoV and NUMB has not been found. These results suggest the TKS4 participation in the invadopodia formation including the actin cytoskeleton rearrangements and indicate its potential involvement in endo-/exocytosis. The analysis of their co-localization in a cell and the functions of TKS4/partners complexes to confirm the identified interaction are in progress.

\section{Acknowledgments}

The author thanks Dr. C. A. Mitchell for cDNA of flag-tagged SHIP, Dr. P. P. Di Fiore for flag-tagged Numb, Dr. S. Gasman for GFP-tagged DNM2, Dr. P. Aspenström for myc-tagged RhoU and RhoV, and Dr. V. V. Filonenko for the kind gift of polyclonal anti-GFP antibodies. The author is grateful to V. Kryklyva for the help in image preparing. The author gratefully acknowledges Dr. O. Gubar for critical reading of the manuscript.

\section{Funding}

This work was supported by the №37/15 grants "Mechanisms of invadopodia functioning and expression of their components in the breast cancer disease" (NAS of Ukraine project "The molecular and cellular biotechnology in medicine, industry and agriculture"). 


\section{REFERENCES}

1. Pawson T. Dynamic control of signaling by modular adaptor proteins. Curr Opin Cell Biol. 2007;19(2):112-6.

2. Reebye V, Frilling A, Hajitou A, Nicholls JP, Habib NA, Mintz $P J$. A perspective on non-catalytic Src homology (SH) adaptor signalling proteins. Cell Signal. 2012;24(2):388-92.

3. Balla T. Inositol-lipid binding motifs: signal integrators through protein-lipid and protein-protein interactions. J Cell Sci. 2005;118(Pt 10):2093-104.

4. Buschman MD, Bromann PA, Cejudo-Martin P, Wen F, Pass I, Courtneidge SA. The novel adaptor protein Tks4 (SH3PXD2B) is required for functional podosome formation. Mol Biol Cell. 2009;20(5):1302-11.

5. Lányi Á, Baráth $M$, Péterfi $Z$, Bogel $G$, Orient A, Simon T, Petrovszki E, Kis-Tóth K, Sirokmány G, Rajnavölgyi É, Terhorst C, Buday L, Geiszt M. The homolog of the five SH3domain protein $(\mathrm{HOFI} / \mathrm{SH} 3 \mathrm{PXD} 2 \mathrm{~B})$ regulates lamellipodia formation and cell spreading. PLoS One. 2011;6(8):e23653.

6. Gianni D, Diaz B, Taulet N, Fowler B, Courtneidge SA, Bokoch GM. Novel p47(phox)-related organizers regulate localized NADPH oxidase 1 (Nox1) activity. Sci Signal. 2009;2(88):ra54.

7. Gianni D, Taulet N, DerMardirossian C, Bokoch GM. c-Src-mediated phosphorylation of NoxA1 and Tks4 induces the reactive oxygen species (ROS)-dependent formation of functional invadopodia in human colon cancer cells. $\mathrm{Mol}$ Biol Cell. 2010;21(23):4287-98.

8. Hishida T, Eguchi T, Osada S, Nishizuka M, Imagawa M. A novel gene, fad49, plays a crucial role in the immediate early stage of adipocyte differentiation via involvement in mitotic clonal expansion. FEBS J. 2008;275(22):5576-88.

9. Bendon CL, Fenwick AL, Hurst JA, Nürnberg G, Nürnberg $P$, Wall SA, Wilkie AO, Johnson D. Frank-ter Haar syndrome associated with sagittal craniosynostosis and raised intracranial pressure. BMC Med Genet. 2012;13:104.

10. Wilson GR, Sunley J, Smith KR, Pope K, Bromhead CJ, Fitzpatrick E, Di Rocco M, van Steensel M, Coman DJ, Leventer RJ, Delatycki MB, Amor DJ, Bahlo M, Lockhart PJ. Mutations in SH3PXD2B cause Borrone dermato-cardioskeletal syndrome. Eur J Hum Genet. 2014;22(6):741-7.

11. Mao M, Solivan-Timpe F, Roos BR, Mullins RF, Oetting TA, Kwon YH, Brzeskiewicz PM, Stone EM, Alward WL, Anderson $M G$, Fingert JH. Localization of SH3PXD2B in human eyes and detection of rare variants in patients with anterior segment diseases and glaucoma. Mol Vis. 2012;18:705-13.

12. Mao M, Thedens DR, Chang B, Harris BS, Zheng QY, Johnson KR, Donahue LR, Anderson MG. The podosomal-adaptor protein SH3PXD2B is essential for normal postnatal development. Mamm Genome. 2009;20(8):462-75.

13. Havrylov S, Rzhepetskyy Y, Malinowska A, Drobot L, Redowicz MJ. Proteins recruited by SH3 domains of Ruk/CIN85 adaptor identified by LC-MS/MS. Proteome Sci. 2009;7:21.
14. Bisson N, James DA, Ivosev G, Tate SA, Bonner R, Taylor L, Pawson $T$. Selected reaction monitoring mass spectrometry reveals the dynamics of signaling through the GRB2 adaptor. Nat Biotechnol. 2011;29(7):653-8.

15. Murphy DA, Courtneidge SA. The 'ins' and 'outs' of podosomes and invadopodia: characteristics, formation and function. Nat Rev Mol Cell Biol. 2011;12(7):413-26.

16. Kropyvko S, Gerasymchuk D, Skrypkina I, Dergai M, Dergai $O$, Nikolaienko O, Rynditch A, Tsyba L. Structural diversity and differential expression of novel human intersectin 1 isoforms. Mol Biol Rep. 2010;37(6):2789-96.

17. Tsyba L, Gryaznova T, Dergai O, Dergai M, Skrypkina I, Kropyvko S, Boldyryev O, Nikolaienko O, Novokhatska O, Rynditch A. Alternative splicing affecting the SH3A domain controls the binding properties of intersectin 1 in neurons. Biochem Biophys Res Commun. 2008;372(4):929-34.

18. Gryaznova T, Kropyvko S, Burdyniuk M, Gubar O, Kryklyva $V, T s y b a$ L, Rynditch $A$. Intersectin adaptor proteins are associated with actin-regulating protein WIP in invadopodia. Cell Signal. 2015 Jul;27(7):1499-508.

19. Gubar OS, Houy S, Billuart P, Kropyvko SV, Tsyba LO, Gasman $S$, Rynditch $A V$. GTPase-activating protein oligophrenin 1 is a new partner of multifunctional adapter protein intersectin 1. Biopolym Cell. 2012;28(5):357-362.

20. Colaluca IN, Tosoni D, Nuciforo P, Senic-Matuglia F, Galimberti V, Viale G, Pece S, Di Fiore PP. NUMB controls p53 tumour suppressor activity. Nature. 2008;451(7174):7680.

21. Dyson JM, O'Malley CJ, Becanovic J, Munday AD, Berndt MC, Coghill ID, Nandurkar HH, Ooms LM, Mitchell CA. The SH2-containing inositol polyphosphate 5-phosphatase, SHIP-2, binds filamin and regulates submembraneous actin. J Cell Biol. 2001 Dec 10;155(6):1065-79.

22. Saras J, Wollberg P, Aspenström P. Wrch1 is a GTPase-deficient $\mathrm{Cdc} 42$-like protein with unusual binding characteristics and cellular effects. Exp Cell Res. 2004;299(2):356-69.

23. Aspenström P, Ruusala A, Pacholsky D. Taking Rho GTPases to the next level: the cellular functions of atypical Rho GTPases. Exp Cell Res. 2007;313(17):3673-9.

24. González-Jamett AM, Momboisse F, Guerra MJ, Ory S, Báez-Matus X, Barraza N, Calco V, Houy S, Couve E, Neely A, Martínez AD, Gasman $S$, Cárdenas AM. Dynamin-2 regulates fusion pore expansion and quantal release through a mechanism that involves actin dynamics in neuroendocrine chromaffin cells. PLoS One. 2013;8(8):e70638.

25. Xie J, Vandenbroere I, Pirson I. SHIP2 associates with intersectin and recruits it to the plasma membrane in response to EGF. FEBS Lett. 2008;582(20):3011-7.

26. Aspenström $P$. The verprolin family of proteins: regulators of cell morphogenesis and endocytosis. FEBS Lett. 2005;579(24):5253-9.

27. Nakano-Kobayashi A, Kasri NN, Newey SE, Van Aelst L. The Rho-linked mental retardation protein OPHN1 controls 
synaptic vesicle endocytosis via endophilin A1. Curr Biol. 2009;19(13):1133-9.

28. McMahon HT, Boucrot E. Molecular mechanism and physiological functions of clathrin-mediated endocytosis. Nat Rev Mol Cell Biol. 2011;12(8):517-33.

29. Faure $S$, Fort P. Atypical RhoV and RhoU GTPases control development of the neural crest. Small GTPases. 2011;2(6):310-313.

30. Drouet V, Lesage S. Synaptojanin 1 mutation in Parkinson's disease brings further insight into the neuropathological mechanisms. Biomed Res Int. 2014;2014:289728.

\section{Нові партнери скафолдного білка TKS4}

С. В. Кропивко

Скафолд TKS4 приймає участь у формуванні інвадоподій, продукції активних форм кисню (ROS) в ракових клітинах та інших клітинних процесах. Мета. Ідентифікувати нових партнерів TKS4, задіяних в перебудовах актинового цитоскелету та ендо-екзоцитозі. Методи. In vitro GST pull-down assay. Результати. Показано, що SH3 домени TKS4 взаємодіють 3 білками-реорганізаторами актинового цитоскелету N-WASP та CR16, а також з DNM2, SYNJ1 та OPHN1, які задіяні в ендо-/ екзоцитозі. Проте взаємодії WIP, WIRE, SHIP2, RhoU, RhoV та NUMB, з SH3 доменами TKS4 не знайдено. Висновки. SH3 домени TKS4 взаємодіють з білками N-WASP, DNM2, SYNJ1, OPHN1 та слабко з CR16 in vitro.

Кл юч о в і с с о в а: TKS4, адаптерні/скафолдні білки, актиновий цитоскелет, ендо-/екзоцитоз

\section{Новые партнеры скаффолдного белка TKS4}

\section{С. В. Кропивко}

Скаффолд TKS4 принимает участие в формировании инвадоподий, продукции активных форм кислорода (ROS) в раковых клетках и других клеточных процессах. Цель. Идентификация новых партнеров TKS4, участвующих в перестройках актинового цитоскелета и эндо-/экзоцитозе. Методы. In vitro GST pull-down assay. Результаты. Показано, что SH3 домены TKS4 взаимодействуют с белками-реорганизаторами актинового цитоскелета N-WASP и CR16, а также с DNM2, SYNJ1 и OPHN1, которые задействованы в эндо-/экзоцитозе. Взаимодействия WIP, WIRE, SHIP2, RhoU, RhoV и NUMB, c SH3 доменами TKS4 не выявлено. Выводы. SH3 домены TKS4 взаимодействуют с белками N-WASP, DNM2, SYNJ1, OPHN1 и слабо с CR16 in vitro.

Кл юч е в ы е с л о в а: TKS4; адапторные/скаффолдные белки; актиновий цитоскелет ; эндо-/экзоцитоз

Received 27.07.2015 